$\begin{array}{lll}\text { KULTURA } & \begin{array}{l}\text { POLSKA A KADEMIANAUK } \\ \text { KOMITET SOCJOLOGII }\end{array} & \text { ISSN 0023-5172 } \\ \text { i } & \begin{array}{l}\text { INSTYTUT STUDIÓW POLITYCZNYCH } \\ \text { SPOLECLENSTWO }\end{array} & \\ \text { 2008, nr } 3 \quad \text { PROBLEMY PŁCI } & \end{array}$

JULITA CZERNECKA

Uniwersytet Łódzki

\title{
SINGIEL I SINGIELKA O ŻYCIU W POJEDYNKĘ
}

Życie w pojedynkę nie jest zjawiskiem nowym, wystepuje w każdym społeczeństwie, epoce i kulturze. Z obserwacji życia codziennego i wielu interdyscyplinarnych badań naukowych wynika, że zmiany zachodzące w ostatnich dekadach we współczesnych społeczeństwach zachodnich doprowadziły do ważnych przemian w rodzinie i związkach małżeńskich. W krajach Europy Zachodniej, Ameryki Północnej i Australii zaczęły upowszechniać się alternatywne wobec rodziny formy życia. Są to: grupy przyjaciół żyjących w jednym gospodarstwie domowym (friends), osoby w stałych związkach, które mieszkają osobno (living apart together), związki homoseksualne oraz tak zwani single, czyli osoby żyjące w pojedynkę.

Pierwsze badania dotyczące osób bezżennych były prowadzone w Stanach Zjednoczonych na przełomie XIX i XX wieku. Amerykańscy badacze zwrócili wówczas uwagę na subkulturę amerykańskich bachelor, czyli starych kawalerów (Chudacoff 1999). Byli to mężczyźni o wysokiej pozycji społecznej, dla których najważniejsze wartości stanowiły wolność i „korzystanie z przyjemności życia” oraz brak stałych zobowiązań, co zapewniało życie bez partnerki. W owym czasie akceptowano także staropanieństwo, jeżeli kobiety zdecydowały się poświęcić swoje życie innym, pełniąc rolę służących, nauczycielek, guwernantek, dam do towarzystwa itp. W innych przypadkach natomiast na jednostki, które nie wstąpiły w związek małżeński, nakładane były dotkliwe sankcje społeczne i ekonomiczne.

Dwie wojny światowe zaburzyły demograficzne proporcje ludności. W owym czasie jednym $z$ głównych powodów życia w pojedynkę stało się wdowieństwo, zwłaszcza kobiet. Pionierskie badania nad innymi przyczynami życia $\mathrm{w}$ pojedynkę, prowadzone $\mathrm{w}$ latach pięćdziesiątych XX wieku, wskazywały, iż ludzie nie wstępowali w związki małżeńskie przede wszystkim dlatego, że byli w trudnej sytuacji życiowej, co wiązało się między innymi ze złym stanem zdro-

Adres do korespondencji: jczernecka@uni.lodz.pl 
wia, brakiem atrakcyjności, kalectwem, zaburzeniami psychicznymi, homoseksualizmem, brakiem edukacji, geograficzną izolacją (Kuhn 1955). W latach sześćdziesiątych ubiegłego stulecia życie społeczne się stabilizowało. Kultura masowa zaczęła mieć coraz większy wpływ na kształtowanie się konsumpcyjnego stylu życia, zwłaszcza w Stanach Zjednoczonych. Przez kolejne dwadzieścia lat zaszło wiele społeczno-ekonomicznych przemian, które przyczyniły się do rozpadu tradycyjnej rodziny i uruchomiły proces tworzenia się jej alternatywnych form. Zmianie w znacznym zakresie uległy dotychczas obowiązujące normy i wartości społeczne związane z rodziną i małżeństwem (między innymi konsekwencją upowszechnienia się środków antykoncepcyjnych było oddzielenie funkcji prokreacyjnej i seksualnej, a także macierzyństwa od instytucji małżeństwa). Przemiany te spowodowały wzrost średniego wieku zawierania pierwszego związku małżeńskiego w krajach zachodnich oraz zmianę proporcji między osobami pozostającymi w związkach małżeńskich i osobami żyjącymi w pojedynkę ${ }^{1}$.

Na Zachodzie, zwłaszcza w Stanach Zjednoczonych, zaczęto rozwijać badania nad zjawiskiem życia w pojedynkę. W latach siedemdziesiątych pisały na ten temat między innymi Marie Edwards i Eleonor Hoover (Edwards, Hoover 1974; Edwards 1977). Jako pierwszy problematykę społecznych uwarunkowań tego zjawiska zgłębił Peter Stein $(1975,1976,1981)$. Od tego czasu zrealizowano wiele różnych badań, poświęconych nie tylko osobom młodym, które nie wstąpiły jeszcze $\mathrm{w}$ związek małżeński, ale także rozwiedzionym, owdowiałym i tym w starszym wieku (Adams 1976; Austrom 1984; Cargan, Melko 1982; Schwartzberg, Berliner, Jacob 1995; Gove, Shin 1989). Warto wspomnieć o pracach Masahiro Yamady (2004), który zajmował się problematyką młodych ludzi, stanu wolnego, niezależnych finansowo, ale nadal mieszkających z rodzicami. Nazwał ich „rozpuszczonymi singlami”, ze względu na to, że nadal korzystają z materialnego wsparcia rodziców, którzy wyręczają ich w codziennych obowiązkach domowych. W latach dziewięćdziesiątych rozwinęły się badania poświęcone zagadnieniom życia samotnych kobiet (Chandler 1991; Dalton 1992; Gordon 1994; Kaslow 1992). Współczesne amerykańskie badania skupione są już raczej nie na przyczynach życia w pojedynkę, ale dotyczą tak zwanego singlizmu, czyli kwestii dyskryminacji i stereotypizacji singli (De Paulo, Morris 2005) oraz procesu ich stygmatyzacji (Kaiser, Kashy 2005).

Również w Polsce na przełomie XX i XXI w. zaobserwowano wzrost liczby jednoosobowych gospodarstw domowych, prowadzonych przede wszystkim przez ludzi młodych i w średnim wieku. Lata dziewięćdziesiąte przyniosły przeobrażenia w sferze politycznej, związane $z$ upowszechnianiem się idei de-

${ }^{1}$ Na przykład w Stanach Zjednoczonych w latach 1975-1999 procent osób w wieku 30-34 lata, które nie weszły w związek małżeński, wzrósł z $6 \%$ do $29 \%$ wśród mężczyzn i z 9,5\% do $21 \%$ wśród kobiet. W ostatnich trzech dekadach odsetek kobiet w wieku 24 lat, które nie są zamężne, wzrósł z $36 \%$ do $72 \%$, a kobiet wieku od 30 do 34 lat z 6\% do $22 \%$ (U.S. Cenzus Bureau 2004; Francese 2003). 
mokratycznych oraz ze zmianami ekonomicznymi, w tym początki funkcjonowania gospodarki wolnorynkowej. Jednocześnie zachodziły zmiany $\mathrm{w}$ sferze społecznej i kulturowej, w tym zmiany świadomościowe i w obszarze wartości. Propagowano idee samorealizacji, wolności wyboru, samorozwoju jednostki. Zmiany w sposobie myślenia doprowadziły do szeroko rozumianej konkurencyjności między normami i wartościami do tej pory uznawanymi w Polsce za tradycyjne a wartościami indywidualistycznymi transmitowanymi z „Zachodu” 2 .

W Polsce badania na temat singli dopiero się rozwijają. Dotychczas tym zagadnieniem zajmowali się między innymi Krzysztof Tymicki (2001), który zanalizował zjawisko bezżenności, starokawalerstwa i staropanieństwa, oraz Ewa Grzeszczyk (2005) i Emilia Paprzycka (2007), które badały młode kobiety żyjące w pojedynkę. Problematykę tę poruszały także Krystyna Slany (2002) oraz Aldona Żurek (2005). Ponieważ do tej pory nie przeprowadzono kompleksowych badań dotyczących stylu życia polskich singli i przyczyn, dla których żyją $\mathrm{w}$ pojedynkę, postanowiłam dogłębnie zbadać ten obszar zagadnień ${ }^{3}$.

\section{DEFINICJA SINGLA}

Terminem „singiel” posługujemy w Polsce dopiero od kilku lat. W dosłownym tłumaczeniu z języka angielskiego single oznacza: pojedynczy, wolny, samotny, kawaler, panna. W Polsce osoby bezżenne nazywano „starymi pannami” lub „starymi kawalerami”, a ich samotność postrzegano jako wynik bezradności, brzydoty czy złego charakteru. Zmiany w systemie wartości wpłynęły na terminy określające osoby żyjące samotnie, jednocześnie przyczyniając się do zmian w społecznej percepcji. Pojawiła się kategoria osób samotnych z wyboru, aktywnych na polu zawodowym i towarzyskim, zadowolonych ze swojego życia „solo”. Taki właśnie wizerunek singli stał się powszechny w środkach masowego przekazu (Czernecka 2008). Nadal jednak funkcjonuje pojęcie staropanieństwa i starokawalerstwa, bazujące na negatywnym stereotypie osób samotnych, kojarzonych z osamotnieniem i biernością.

W życiu codziennym pojęciem „singiel” często posługujemy się niejako intuicyjnie. Jednak precyzyjne jego określenie natrafia na pewnego rodzaju trudności. $Z$ perspektywy formalnej single to osoby stanu wolnego, nie będące w związku małżeńskim, a w kontekście społecznym to osoby, które nie mają stałego partnera. Większość autorów twierdzi, że konstytutywną cechą singla jest wybór życia w pojedynkę. Ewa Grzeszczyk pisząc o single professional women

2 Badania CBOS czy OBOP opisują zmiany dokonujące się w obszarze wartości życiowych Polaków: od rodziny, która lokowała się zwykle na pierwszym miejscu w rankingach, do znacznego wzrostu znaczenia samorealizacji w sferze zawodowej i samodzielności ekonomicznej oraz wzrostu wagi wykształcenia. Następuje przechodzenie od wartości kolektywistycznych do tych o charakterze indywidualistycznym oraz od wartości związanych ze społeczeństwem tradycyjnym do wartości lansowanych w społeczeństwach nowoczesnych czy ponowoczesnych.

3 Przedstawiam tu w część wyników mojej pracy doktorskiej poświęconej temu problemowi. 
definiuje je jako kobiety heteroseksualne, niezamężne lub nie mające stałego partnera, pracujące zawodowo, mające ponad średnie wykształcenie i mieszkające w dużych miastach (Grzeszczyk 2005). Emilia Paprzycka „nowe samotne kobiety" definiuje również jako kobiety wykształcone, niezależne finansowo, niepozostające w stałym związku (Paprzycka 2007). Z kolei Krystyna Slany wskazuje, że single podejmują decyzję o takim sposobie życia, ale samotność nie jest dla nich wyborem ostatecznym. Uczestniczą bardzo aktywnie w konsumpcji dóbr kulturalnych i materialnych, które w wielkich miastach tworzone są specjalnie dla nich. Singli łączy często wspólne miejsce zamieszkania (Slany 2002). Jeszcze inny sposób wyjaśnienia tego pojęcia proponuje Aldona Żurek, według której są to „osoby, które nie podjęły jeszcze decyzji o zmianie ich statusu rodzinnego, te, które w wyniku splotu okoliczności życiowych zostały postawione przed koniecznością życia samotnego i samodzielnego oraz które dokonały wyboru takiego stylu życia. [...] struktura wieku singli obejmuje osoby bardzo młode, często uczące się lub studiujące, jak i takie, które znajdują się w fazie późnej dorosłości i starości" (Żurek 2005, s. 77). Tutaj mianem singli będę określała osoby młode, które mieszkają w wielkich miastach, zwykle mają ponad średnie wykształcenie, są bezdzietne i nie pozostają $\mathrm{w}$ stałym związku.

\section{PROBLEMATYKA I PRZEDMIOT BADAŃ}

W ostatnich latach w środkach komunikacji masowej obserwujemy wzrost zainteresowania problematyką singli. Pod koniec lat dziewięćdziesiątych w Polsce popularne stały się seriale i filmy o singlach (m.in. Ally McBeal, Sex w wielkim mieście, Dziennik Bridget Jones oraz Magda M). Zaczęto publikować artykuły o singlach, pojawiły się audycje telewizyjne oraz radiowe dotyczące tego tematu, powstało także wiele forów internetowych o singlach i dla singli ${ }^{4}$ oraz portali randkowych ${ }^{5}$. Ukształtował się stereotypowy wizerunek singli, przedstawianych jako ludzie młodzi, ponadprzeciętnie wykształceni, zamożni, mieszkający $\mathrm{w}$ wielkich miastach, pracujący na ogół $\mathrm{w}$ wolnych zawodach, zadowoleni z życia „solo”. W powszechnej opinii, lansowanej przez środki komunikacji masowej, główne przyczyny życia w pojedynkę to zaangażowanie w pracę zawodową, rozwijanie kariery, brak czasu na budowanie trwałych związków, pogoń za idealną miłością, brak odpowiednich kandydatów na partnera, miejski styl życia, moda na „bycie singlem” (Czernecka 2008).

4 Zob. m.in. „Strefa singla” - forum „Gazety Wyborczej”; www.samotni.mojeforum.net; www.singleisingielki.fora.pl.

5 Tematykę singli spopularyzowały także licznie powstające $\mathrm{w}$ tym czasie portale randkowe, między innymi www.single.pl i ogólnopolska promocja tego portalu na billboardach, a także www.ilove.pl; www.sympatia.pl; www.uwodzenie.net.pl; www.mojamilosc.pl; www.randka.iq.pl. 
Na podstawie obserwacji własnych i analiz chciałam ustalić, w jakim stopniu środki masowego przekazu trafnie i wiarygodne przedstawiają powody, dla których młodzi Polacy żyją w pojedynkę. Postawiłam sobie dwa pytania badawcze: Dlaczego młodzi ludzie w Polsce są singlami i jaki jest ich styl życia? Przeprowadziłam sześćdziesiąt wywiadów swobodnych z trzydziestoma kobietami i trzydziestoma mężczyznami. Dobór próby był celowy, a respondentów pozyskiwano metodą kuli śniegowej, którą stosuje się do badania specyficznych kategorii społecznych. Przedmiotem badania były osoby w wieku 25-40 lat ${ }^{6}$, mieszkające w wielkich miastach (powyżej 500 tys. mieszkańców ${ }^{7}$ ), nie mające partnera, bezdzietne, $z$ ponad średnim wykształceniem. Nie uwzględniałam w swoich badaniach osób, które żyły w pojedynkę z powodów losowych (takich jak śmierć partnera, przewlekła choroba, kalectwo). Średnia wieku respondentów wynosiła 33 lata. Badania były prowadzone na przełomie lat 2006/2007.

Zamierzam tu przedstawić, na jakie przyczyny życia w pojedynkę — przeze mnie zaliczone do obszaru czynników mikrospołecznych - powoływali się badani. Były to:

- negatywne doświadczenia w związkach własnych (21 wypowiedzi);

- negatywny „obraz” związków rodziców (20 wypowiedzi);

- bardzo silne więzi z rodziną (13 wypowiedzi);

— negatywny „obraz” związków przyjaciół (12 wypowiedzi);

- brak doświadczenia w związkach (10 wypowiedzi);

— szczęśliwe małżeństwa rodziców jako „niedościgniony” ideał (9 wypowiedzi);

— życie w pojedynkę jako „naturalna konsekwencja” bycia jedynakiem (7 wypowiedzi);

— inne (10 wypowiedzi).

${ }^{6}$ Do badania wybrałam grupę wiekową 25-40-latków. Dla ludzi w tym wieku, po pierwsze, bardzo istotną rolę odgrywa przede wszystkim rozwój osobisty, zdobywanie wykształcenia i rozwój kariery zawodowej, co ma wpływ na opóźnianie decyzji o zawieraniu trwałych związków i zakładaniu rodziny. Po drugie, środki masowego przekazu pisząc o singlach biorą pod uwagę tę właśnie kategorię wiekową (Czernecka 2008). Po trzecie, z analiz danych GUS wynika, że w Polsce w ciągu ostatnich lat przybyło jednoosobowych gospodarstw domowych, które tworzą właśnie osoby około trzydziestki. Wybrałam tę grupę wiekową także dlatego, że po 1989 roku w niej zanotowano największy przyrost osób ze średnim i wyższym wykształceniem, odznacza się ona też najwyższym wskaźnikiem aktywności zawodowej. Stan cywilny może być z jednej strony czynnikiem wpływającym na aktywność na rynku pracy, z drugiej strony może być efektem sytuacji materialnej bezpośrednio związanej z aktywnością na rynku pracy.

7 Większość osób badanych mieszkała w Łodzi, a także w Warszawie i Poznaniu. Zdecydowałam tak, ponieważ badania naukowe pokazują, że odsetek osób żyjących samotnie jest stosunkowo wysoki zwłaszcza w dużych metropoliach, wśród ludzi legitymujących się wysokim poziomem wykształcenia i wysokim poziomem dochodów, uważanych za „ludzi sukcesu” (zob. np. Hoorn 2000). Marek Szczepański i Bogdan Jałowiecki w odniesieniu do nich używają pojęcia klasy metropolitarnej, której podstawowymi cechami stylu życia jest „dążność do kariery, pracoholizm, luźne związki seksualne, odkładanie założenia rodziny, a szczególnie posiadania dzieci, na później i luksusowa konsumpcja" (Jałowiecki, Szczepański 2002, s. 298). 
Przedstawię tu tylko te przyczyny i motywy życia w pojedynkę, które respondenci wymieniali najczęściej.

\section{NEGATYWNE DOŚWIADCZENIA WE WCZEŚNIEJSZYCH ZWIĄZKACH}

Najczęściej wymienianą przez respondentów przyczyną życia w pojedynkę były wcześniejsze negatywne doświadczenia w życiu we dwoje. Wypowiedzi dotyczyły przede wszystkim tak zwanych związków „poważnych”, czyli tych, które badani uważali za „długoterminowe” [K22], „trwałe” [M30], „związek narzeczeński” [M16], „związek konkubinacki” [M14] — jednym słowem związki, które ich zdaniem miały być „na całe życie” [K17]. Ten powód podawały także osoby, które miały doświadczenia zarówno w związkach „poważnych”, jak i „przelotnych”, te drugie były utożsamiane z „romansem” [K17], „związkiem niedojrzałym” [K2], „krótką przygodą” [K8], „krótkim związkiem” [K21].

Tabela 1

Typ doświadczeń singli w życiu we dwoje

\begin{tabular}{|l|c|c|c|}
\hline \multicolumn{1}{|c|}{ Typ doświadczeń } & Ogółem & Kobiety & Mężczyźni \\
\hline Brak doświadczenia w życiu we dwoje & 11 & 9 & 2 \\
Związki wyłącznie „przelotne” & 11 & 5 & 6 \\
Związki wyłącznie „poważne” & 22 & 8 & 14 \\
Związki „poważne” i „przelotne” & 16 & 8 & 8 \\
\hline Liczba wypowiedzi ogółem & 60 & 30 & 30 \\
\hline
\end{tabular}

Badani wymieniali wiele powodów, dla których nie chcą się z nikim wiązać na stałe. Ogólnie rzecz ujmując, osoby, które były w „poważnych” związkach, często kilku-, a nawet kilkunastoletnich, mówiły o poczuciu zranienia przez partnera, z którym próbowali ułożyć sobie życie. Część poruszyła wątek dotyczący prawdziwej miłości, którą przeżyli i która — jak sądzą — już się w ich życiu nie powtórzy. Mówili, że kochali „naprawdę” wyłącznie jedną osobę i trudno im się pogodzić z tym, że związek rozpadł się, ponieważ druga strona nie chciała podjąć ostatecznej decyzji o zawarciu małżeństwa. Niektórzy przyznawali, że odmienne postawy i plany na przyszłość partnerów spowodowały, iż bardzo zawiedli się na "prawdziwych” związkach i dlatego teraz są sami: „raz byłam narzeczoną, z pierścionkiem zaręczynowym, zostałam porzucona [...], tak naprawdę to kochałam chyba tylko jednego mężczyznę w moim życiu, $z$ którym nie mogę w tej chwili być [...], mało w to wierzę, że poukładam sobie życie $\mathrm{z}$ mężczyzną i $\mathrm{w}$ byciu singlem odnajduję pozytywne strony" [K7, L30, PPL] ${ }^{8}$; „byłam związana przez cztery lata z mężczyzną, z którym planowałam

8 Oznaczenia przy wypowiedziach respondentów zawierają następujące informacje: płeć i numer respondenta, wiek, typ doświadczenia $\mathrm{w}$ życiu we dwoje (P - związki poważne, PL - związki przelotne, PPL — związki poważne i przelotne, B — brak doświadczenia w życiu we dwoje). 
życie wspólne i ślub, natomiast $\mathrm{w}$ momencie deklaracji okazało się, że to nie jest nasz wspólny pomysł [...]. Rozstaliśmy się, co nie znaczy, że to bycie samą to jest spełnienie moich marzeń [...] dochodzę do takiej względnej równowagi i dobrze się czuję z tym, ze samą sobą przede wszystkim [...], ale na razie nie chcę się wiązać, a romanse mnie męczą" [K17, L32, PPL]; ,jestem sama dopiero od czterech lat, choć odczuwam to boleśnie, byłam związana przez czternaście lat $z$ jednym facetem [...] nie legalizowaliśmy tego związku, bo zawsze mówił, że zdążymy, ja w pewnym momencie bardzo pragnęłam dziecka i od tego zaczęły się nasze problemy, on odsuwał się ode mnie, okłamywał mnie i niby także chciał dziecka, ale już szukał innej i znalazł" [K28, L41, P].

Kolejnym motywem, dla którego respondenci nie chcą się ponownie wiązać, były przeżycia związane ze zdradą, której dopuścił się partner: „do naszego rozstania przyczyniła się jej zdrada [...] mieliśmy poważną rozmowę, żeby sobie wszystko wyjaśnić i być już razem do końca życia [...]. Jak mieszkała ze mną, mówiła, że mnie kocha, sypiała ze mną, a w tym samym czasie sypiała $z$ innym, przez pół roku. Tego nie byłem w stanie wybaczyć, nie permanentnej, zaplanowanej zdrady, z premedytacją. To było trzy lata temu" [M1, L33, PPL]; „mój partner, był osobą, której nie mogłam ufać, bo spotykał się ze mną i innymi dziewczynami jednocześnie, także zawiodłam się na nim, po prostu mnie oszukał kilka razy i stwierdziłam, że związki nie mają sensu" [K9, L32, P]. Te przeżycia były dla nich tak silne, że mimo upływu lat postanowili nie wiązać się ponownie.

Silne zaangażowanie $\mathrm{w}$ pracę zawodową również było wymieniane jako powód rozpadu stałych związków: „za mało czasu sobie poświęcaliśmy [...]. Właśnie tamten długi związek skończył się przez to, że spełniałem się w pracy, zajmowałem się robieniem jakiejś tam kariery i od jakiegoś czasu pod jednym dachem nie żyła para ludzi tylko dwa niezależne byty. Zajęci swoimi sprawami i zatracający się w tym” [M14, L41, PPL]; „miałem myśli, żeby z dziewczyną zalegalizować związek [...], ale za bardzo pochłonęła mnie praca, większość wolnego czasu poświęcałem na rozkręcenie firmy. Mieliśmy coraz mniejszy kontakt, mimo że mieszkaliśmy ze sobą, ale w domu byłem tylko gościem. Która kobieta wytrzyma brak bliskiej osoby, częste wyjazdy do Warszawy, Poznania, Szczecina, zaczęły się jakieś podejrzenia, że te wyjazdy to nie tylko ze względu na pracę" [M17, L27, PPL].

Respondenci mówili także o tym, że partnerzy lub oni sami przeprowadzili się do innego miasta lub zagranicę, na przykład z powodu zmiany pracy lub otrzymania stypendium. Związki na odległość nie przetrwały próby czasu ze względu na sporadyczny kontakt, zaangażowanie we własne sprawy, co prowadziło do „wygaśnięcia” uczucia i rozpadu więzi między partnerami - nawet gdy związki były do tej pory szczęśliwe i miały kilkuletnią historię: „kierunki świata się rozjechały, stypendia zagraniczne, gdzie ja pojechałem w jedną stronę, a ona w drugą stronę. I jak byliśmy tutaj to wszystko było pięknie, rewelacyjnie, ale później ta odległość zrobiła swoje i czas, kiedy się nie widzieliśmy razem. Te 
pół roku, potem się przedłużyło do roku, w sumie można powiedzieć, że nawet do dwóch lat. Każdy będąc tam na odosobnieniu zaczyna sobie ten malutki świat budować i przystawać się do otocznia, w którym jest i żeby egzystować $\mathrm{w}$ innym świecie, trzeba wyprzeć to, że jest druga osoba [...] człowiek zaczyna żyć własnym życiem i potem te dwa życia jest połączyć ciężko" [M2, L28, P]; „miałam kiedyś narzeczonego, on był operatorem pracował przy robieniu filmów, byliśmy ze sobą cztery lata. Wszystko było w miarę dobrze jak pracował w Warszawie, ale potem dostał pracę w Londynie i wyjechał. I tak się spotykaliśmy, co kilka miesięcy, powiedzmy raz na trzy miesiące. On tu przyjeżdżał, potem ja tam, nawet zdecydowałam się pojechać do Londynu, poszukać pracy i pojechałam, ale takiej pracy, która by mnie nie zainteresowała, to nie było, tak się tułałam. On się obracał $w$ takim high lifie, więc tak było głupio powiedzieć, że się pracuje jako kelnerka. Nie wytrzymałam i wróciłam do Polski. Rozmawialiśmy o przyszłości, ja chciałam jakoś sformalizować związek, ale on nie bardzo, potem coraz częściej się kłóciliśmy na temat tego, że on tam, ja tu, że on nie chce wrócić na stałe. Zawsze mówił, że do końca projektu, a potem był kolejny i kolejny. I tak się kiedyś pokłóciliśmy, że ja powiedziałam stop i się rozstaliśmy. Tak dłużej być nie mogło, bo to już przestawał być związek" [K27, L38, PPL].

Jeszcze innym motywem, o którym mówili respondenci, było odczuwanie czegoś w rodzaju zmęczenia po wieloletnim „byciu razem”. Te osoby życie w pojedynkę traktują jako swoistą „przerwę” po „poważnych” związkach: „mój poprzedni związek był taki, że ja absolutnie robiłem wszystko, żeby tamta osoba była szczęśliwa. Dopasowałem siebie, swoje życie, swój rytm pracy, swoje gusta do tej osoby [...]. Po sześciu latach odzyskałem siebie" [M15, L41, P]; „dlaczego żyję w pojedynkę? Przez dwanaście lat byłam w związku konkubinackim, a teraz tak się potoczyło a nie inaczej, że jestem sama i tak naprawdę to jest mi z tym bardzo dobrze” [K4, L33, P]; „czuję potrzebę wyluzowania się po tych związkach długoletnich, zmieniłem strategię tak pół żartem pół serio mówiąc. Po prostu po dwóch długich związkach, które mi zajęły ponad pięć lat życia, postanowiłem trochę odpocząć" [M10, L28, P]. Pojawiła się także wypowiedź kobiety, która odeszła od długoletniego partnera, ponieważ uważała ten związek za nieudany i bała się, że przekreśli sobie szansę na znalezienie w przyszłości prawdziwej miłości: „myśmy kompletnie do siebie emocjonalnie nie pasowaliśmy, [...] po ośmiu latach zdecydowałam się to zerwać, bo stwierdziłam, że to nie ma sensu [...] po prostu dłużej już nie mogłam tego znieść. Niby było OK, ale to wszystko siadało ze strony emocjonalnej, mojej. Nie było chemii od początku. Było przywiązanie, była miłość, ale nie było tego czegoś” [K22, L38, PPL]. Respondentka przyznała, że do definitywnego skończenia związku motywował ją strach przed samotnością. Bała się, że mimo iż będzie miała stałego partnera, związek nie będzie oparty na prawdziwej miłości, lecz na przyjaźni, a - jak dodała - „nigdy nie wyszłabym za mąż z przyjaźni". 
Dość często jako przyczynę rozstań wskazywano także niezgodność charakterów partnerów i niedopasowanie temperamentów oraz światopoglądów: „nam się bardziej wydawało, że chcemy być razem i jednak jak się spędza z kimś więcej czasu to wychodzi to niedopasowanie” [K25, L28, PPL]; „to się rozpadło, bo nie pasowaliśmy do siebie, jeżeli chodzi o charakter, poza tym zaczęliśmy sobie przeszkadzać. Wydawało mi się, że to jednak nie jest to" [M12, L28, P]; „przyczyny rozpadu naszego związku, to coś jakby niezgodność charakterów, inne wymagania w stosunku do siebie, inne podejście" [M13, L30, P]. Pewien mężczyzna przyznał, że po wielu nieudanych próbach zbudowania trwałego związku i perypetiach miłosnych, które skończyły się dla niego porażką, pozostanie na zawsze singlem: „doświadczenia w związkach mam fatalne. Mój pierwszy poważny związek był w Kanadzie z Japonką M., trwał prawie rok [...] to było fatalne zauroczenie [...]. Następny trwał trzy miesiące, musiałem znaleźć kogoś po M. Potem długo miałem doraźne kontakty niż związki [...]. Poznałem R., która była siostrą mojego przyjaciela, związek z nią trwał ponad dwa lata. Potem był związek z J., to była Polka, wyjechaliśmy do Amsterdamu, związek trwał pół roku. Związek z J. rozpadł się, bo oboje byliśmy zafascynowani możliwościami w Amsterdamie, ona znalazła sobie Holendra, ja Wenezuelkę. Potem dużo przygodnych związków. Najdłuższy z Wenezuelką, ogólnie stabilny, mieszkaliśmy razem [...] związek był oparty bardziej na doświadczeniach erotycznych niż na uczuciach. [...] Dalej znów przygodne związki i potem półtoraroczny związek we Włoszech, z Włoszką, bardzo urocza, pracowała jako choreograf ze mną teatrze. Dalej długo nic. W Hamburgu związki krótkotrwałe i związek $\mathrm{z}$ K. w Warszawie, który trwał dobry rok. W czasie tego związku trwał już drugi związek w Łodzi z inną kobietą i to był ostatni związek. Związek z K. zakończył się, bo odczuwała potrzebę macierzyństwa i zażądała moich działań w tym kierunku" [M8, L38, P]. Obecnie mężczyzna deklaruje, że jego relacje z kobietami mają i będą miały w przyszłości fizyczny charakter, co polega wyłącznie na zaspokajaniu potrzeb seksualnych.

Rozpadowi związku towarzyszą rozmaite odczucia, większość z nich ma charakter negatywny, jak żal, poczucie straty, rozgoryczenia, smutek. Im ważniejszy był dla respondentów związek, tym silniej i dłużej odczuwają związane z nim emocje. Dla niektórych utrata „jedynej i prawdziwej miłości” była tak bolesna, że nie chcą tworzyć nowych związków i wybierają życie w pojedynkę, uważając je za „mniejsze zło”. Życie takie stało się dla nich sposobem egzystencji, budowania poczucia bezpieczeństwa, komfortu psychicznego, pewności, że nikt nigdy już ich nie zrani. Warte uwagi jest to, że dziesięć osób, które w okresie wczesnej dorosłości ${ }^{9}$ przeżyły miłosne rozczarowanie, nie podejmowało później prób budowania stałych relacji. I mimo ukończenia trzydziestu lat, a nawet przekroczenia tego wieku, nie nawiązali innych związków, ani tych „poważnych”, ani „przelotnych”. Dla innych zaś życie w pojedynkę stało

\footnotetext{
${ }^{9}$ Do czasu ukończenia studiów, czyli do 24 roku życia.
} 
się rodzajem „odpoczynku” od trwałego związku, przedłużającą się „przerwą" $\mathrm{w}$ dotychczasowym życiu „w duecie”. Funkcjonowanie w nieudanych związkach doprowadziło niektórych badanych do wniosku, że lepiej żyć w pojedynkę, poznać siebie, rozwijać swoje pasje, niż tkwić w relacjach, które „nie mają przyszłości". Współcześnie dla młodych ludzi najważniejsze stają się głębokie emocjonalnie i zażyłe związki, oparte na wzajemnym szacunku, wspólnych wartościach i celach życiowych (Pospiszyl 1996). Pod wpływem rozmaitych doświadczeń, przejść i kryzysów w związkach doszli do wniosku, że lepiej żyć w pojedynkę niż „z byle kim i byle jak”.

\section{NEGATYWNY OBRAZ ZWIĄZKÓW RODZICÓW}

Drugą najczęściej wymienianą przez respondentów przyczyną życia w pojedynkę był negatywny obraz związku rodziców, czyli doświadczenia wyniesione $z$ rodziny pochodzenia.

Tabela 2

Typ rodziny pochodzenia ze względu na rodzaj związku rodziców

\begin{tabular}{|l|c|c|c|}
\hline \multicolumn{1}{|c|}{ Typ rodziny } & Ogółem & Kobiety & Mężczyźni \\
\hline Rodziny pełne & 43 & 22 & 21 \\
Rodziny niepełne & 17 & 8 & 9 \\
\hline Łączna liczba wypowiedzi & 60 & 30 & 30 \\
\hline
\end{tabular}

Dla dwunastu osób wychowanych w rodzinach niepełnych, motywem, dla którego nie chcieli podejmować prób życia w stałym związku, były złe doświadczenia małżeńskie ich rodziców oraz brak pozytywnych wzorów życia we dwoje. Część z nich wskazywała, że jednym $z$ argumentów przemawiających za życiem w pojedynkę są różnego rodzaju urazy i lęki przed wchodzeniem $\mathrm{w}$ związek $\mathrm{z}$ drugą osobą, stanowiące pewnego rodzaju piętno pozostawione przez rozpad związku rodziców. Świadczy o tym między innymi wypowiedź mężczyzny, który po rozwodzie rodziców doświadczył problemów natury psychologicznej, polegających na odczuwaniu silnego lęku na samą myśl o tym, że każdy związek może się rozpaść, niezależnie od tego, ile energii i zapału poświęci się jego budowaniu: „podejmujesz kroki, formalizujesz związek, bierzesz ślub, są dzieci, jest wszystko fajnie, ale jest tam gdzieś ukryty strach, że to może nie wypalić, to się bierze gdzieś z tych moich wcześniejszych doświadczeń. Ja mam w głowie, że to ta druga strona będzie chciała zakończyć związek, a nie ja, i to jest takie niepokojące u mnie" [M17, L28, PPL].

Inny mężczyzna, którego rodzice się rozwiedli, gdy miał kilkanaście lat, był przekonany, że jego obecne obawy dotyczące nawiązywania trwałych związków wynikają z braku pozytywnego wzoru relacji partnerskich. Akcentował fakt, że w małżeństwie jego rodziców brakowało wzajemnych poświęceń i kompromisów, dlatego - jak sądzi - podjęli decyzję o rozwodzie: „na pewno miało 
to na mnie jakiś wpływ, że się rozwiedli. Być może brakowało właśnie tych poświęceń [...] i to stąd, teraz wolę czerpać więcej korzyści niż się poświęcać" [M11, L30, P]. Stwierdził, iż zdaje sobie sprawę z tego, że taki sposób zachowania negatywnie wpływa na relacje $z$ kolejnymi partnerkami i staje się przyczyną rozpadu związków. Bardzo boleśnie przeżyła rozwód rodziców także respondentka, która jako mała dziewczynka była świadkiem ich ostrej walki o sprawowanie nad nią opieki. Stwierdziła, że małżeństwo ją „absolutnie przeraża" [K22, L38, PPL] i przyznała, że przyczyną mogą być wspomnienia, o tym jak trudno było jej matce uzyskać rozwód $z$ ojcem. Respondentka dodała, że nie ma pozytywnego wzorca związku, ponieważ inne związki jej rodziców także nie układały się dobrze: ,jak byłam na studiach, to moja mama żyła z jednym facetem parę lat, ale to się rozpadło. A mój tata [...] rozwiódł się z drugą żoną rok temu i ma w tej chwili narzeczoną cztery lata ode mnie młodszą, ale powiedział, że nie weźmie ślubu, bo to nie ma sensu, więc ja nie mam w ogóle takiego modelu [związku - J.Cz.]" [K22, L38, PPL].

Osoby pochodzące $z$ rodzin, $w$ których jedno $z$ rodziców umarło, nie odwoływały się w wypowiedziach do relacji rodziców. Tylko jedna respondentka stwierdziła, że świadomie lub podświadomie ma pewne zahamowania przed wchodzeniem w stałe związki, ponieważ nie doświadczyła żadnych pozytywnych przykładów w swojej rodzinie - małżeństwo jej rodziców nie istnieje, matka nie żyje od wielu lat, ojciec $z$ nikim się ponownie nie związał, ponadto jej dwie najbliższe ciotki miały mężów alkoholików, a trzecia jest starą panną [K14, L29, PPL]. Pozostali respondenci przyznali, że śmierć matki lub ojca nastąpiła $\mathrm{w}$ dzieciństwie i nie pamiętają, jakie relacje panowały między nimi (ich rodzice nie związali się $\mathrm{z}$ nikim ponownie ani $\mathrm{w}$ sensie formalnym, ani nieformalnym), co także może świadczyć o tym, że nie posiadają wzoru relacji odnoszącego się do ich rodziny pochodzenia.

Ośmiu respondentów pochodzących z rodzin pełnych przyznało, że to właśnie złe relacje między matką a ojcem - to znaczy częste konflikty, awantury, wzajemny brak szacunku - zaważyły o wyborze przez nich samotnego życia i wywołały niechęć do tworzenia stałych związków. Przyznali, że ich obecna sytuacja życiowa jest konsekwencją ostrożnego dokonywania wyboru parterów. Motywem ciągłego odrzucania potencjalnych kandydatów był negatywny obraz stosunków panujących między rodzicami. Niektórzy z badanych twierdzili, że nie wyobrażają sobie, aby mogli egzystować w podobnym małżeństwie i woleliby żyć sami niż ze źle dobranym partnerem: „moi rodzice są małżeństwem już ze trzydzieści lat i mieli poważne kryzysy w swoim związku, bo się zwyczajnie źle dobrali, ja tak nie chcę, wolę poczekać na odpowiedniego faceta" [K8, L27, $\mathrm{P}]$; „moi rodzice są małżeństwem trzydzieści cztery lata i wydaje mi się, że nie są szczęśliwym małżeństwem, bo mają inny sposób myślenia o świecie, o sobie, mają inne plany, inne priorytety, które się ze sobą nie pokrywają, co jest przecież $\mathrm{w}$ małżeństwie bardzo ważne, dlatego ja nie chciałbym popełnić ich błędu” [M6, L35, P]; „moi rodzice są małżeństwem z trzydzieści parę lat 
i ich związek jest fatalny, różnią się charakterami, postawami, poglądami, żyją razem, bo się nauczyli siebie tolerować, przyzwyczaili się do siebie, ja wolę być sam” [M8, L38, P]. Zwłaszcza dwaj ostatnio cytowani mężczyźni [M6; M8] obawiali się, że na początku znajomości każda partnerka wydaje się idealna, a z czasem jej charakter może ulec zmianie. Byli przeświadczeni, że w konsekwencji prowadzi to do pojawia się rozmaitych rozbieżności w postrzeganiu świata i chęci realizacji odmiennych wizji życia.

Innym motywem wskazanym przez jednego $z$ respondentów była - jak sądził — jego „postawa zamknięta” [M1, L33, PPL] wobec „bycia w związku” i brak zaufania do potencjalnych partnerek. Wielokrotnie podkreślał, że gdyby małżeństwo jego rodziców było zgodne i szczęśliwe, to prawdopodobnie obecnie byłby w stanie o wiele łatwiej „otworzyć się” na znajomość z drugą osobą i szybciej jej zaufać: „od bardzo młodego wieku wiele rzeczy zacząłem widzieć, myśleć, ponieważ $\mathrm{w}$ małżeństwie moich rodziców było różnie, to sobie tak kodowałem, taką naukę na przyszłość, żeby dobrze wybrać, mocno się zastanowić i żeby dbać o to wszystko [...]. Rodzice mieli stałych kochanków, wiedzieli o nich, nawet znałem kochankę ojca, przez kilka lat był z tą samą kobietą. Myślę, że gdybym dostał początkowo pozytywny obraz od rodziców, to potem w życiu weryfikacja [tworzenia związków - przyp. J.Cz.] byłaby całkiem inna niż teraz" [M1, L33,PPL]. Niestety, jak sam przyznaje, w wyniku tych przemyśleń zbudował sobie „teorię idealnego związku”, a jego problem — jak sam przyznał - polega na tym, że „nie dostrzega” wokół siebie kobiet, z którymi teorię tę mógłby wprowadzić w życie.

Kolejną przyczynę życia w pojedynkę podała respondentka, której rodzice od dłuższego czasu nie mieszkali ze sobą, choć nadal formalnie pozostawali małżeństwem. Przyznała, że uświadomiło jej to, iż do stworzenia udanego związku nie wystarczy jedynie wola dwójki kochających się ludzi. Na to, czy związek jest udany czy nie, wpływa także wiele innych czynników, chociażby takich jak umiejętność osiągania kompromisów: „moi rodzice są małżeństwem, nie są $\mathrm{w}$ żadnej separacji, a jakiś czas temu postanowili, że nie mogą mieszkać ze sobą razem, bo by się chyba zabili, faktycznie jest tak, że są dość dużymi indywidualistami i każdy z nich potrzebuje dużo większej przestrzeni dla siebie" [K17, L32, PPL]. Ów brak chęci wypracowania wspólnych rozwiązań dla problemów, przed którymi stanęli, tak przygnębił respondentkę, że - jak przyznała - w dużej mierze zaczęła postrzegać życie we dwoje w nie do końca pozytywnym świetle.

Obserwacja nieudanych, nieszczęśliwych związków małżeńskich rodziców u większości dorosłych już dzieci powoduje silne napięcie emocjonalne, różnego rodzaju zahamowania, bierne postawy i tendencję do wycofywania się z wielu ważnych sytuacji społecznych (Dąbrowska 2001). W związku z tym, $\dot{z}$ e „W domu rodzinnym spotykamy się po raz pierwszy z małżeństwem ucieleśnionym w postępowaniu ojców i matek ze sobą i wobec siebie" (Przybył 2001, s. 112), osoby pochodzące $z$ rodzin niepełnych i nieudanych mogą mieć silnie 
zakorzeniony negatywny obraz życia we dwoje lub nie mieć w tym zakresie żadnego wzorca. Część z nich wybiera życie w pojedynkę jako „mniejsze zło”, a nawet jako lepszy sposób funkcjonowania. Ich liczne obawy, w połączeniu $z$ ubogą wiedzą na temat pozytywnych stron życia w parze, mogą przekładać się na niechęć do życia w związku lub trudności w kontaktach z potencjalnymi partnerami.

\section{BARDZO BLISKIE WIĘZI Z RODZINĄ}

Zdecydowana większość singli określała swoje więzi z rodziną jako bliskie, silne i bardzo dobre. Ich wypowiedzi wskazywały, że mają wyjątkowe relacje z najbliższą rodziną, czyli rodzicami i rodzeństwem. Mówili przede wszystkim o silnych związkach emocjonalnych: ,jestem bardzo zżyta z moimi rodzicami i siostrą, oni ciągle są dla mnie najważniejsi” [K13]; „mam swoją rodzinę i ona jest niesamowita, trzymamy się razem i potrafimy sobie zawsze pomagać” [M21]; ,jestem bardzo związana emocjonalnie ze swoją rodziną” [K23]; „W naszej rodzinie te związki są bardzo silne, nie są jakoś wymuszone, nie ma tak, że spotykamy się z inicjatywy tylko jednej strony wyłącznie” [M4]. Trzynastu badanych przyznało, że to właśnie relacje $z$ najbliższą rodziną stały się głównym powodem ich życia w pojedynkę.

Niektórzy respondenci kwestię „zbyt” silnych więzi łączących ich z najbliższymi postrzegali jako nadrzędny wobec innych motyw życia „solo”. Jedna z kobiet, stwierdziła, że czuje się bardzo mocno, wręcz symbiotycznie związana $z$ rodzicami i z tego powodu nie „śpieszy się” jej do bycia w związku „na serio": „jestem może trochę za bardzo zżyta z moją rodziną i ciągle jest dla mnie najważniejsza, zawsze nawet na noc lub nad ranem wracałam od chłopaka do swojego domu, i tak te związki trochę nie do końca traktowałam poważnie. Zawsze rodzice i siostra byli dla mnie najważniejsi" [K13, L30, P].

Inni mówili o „za długim” - ich zdaniem - okresie mieszkania z rodzicami. Dwaj mężczyźni wysnuli przypuszczenie, że może to mieć związek z ich życiem $w$ pojedynkę: „mieszkam $z$ rodzicami, od zawsze, $z$ tą roczną przerwą na Warszawę, nie wiem, może to też ma wpływ, że ciągle jestem sam" [M23, L33, B]; „relacje z rodzicami są dobre, są bliskie, partnerskie i przyjacielskie, mieszkam z nimi, czasem się zastanawiam, czy tylko nie z wygody" [M28, L35, P]. Jedna $z$ badanych była przeświadczona, iż to, że dopiero niedawno wyprowadziła się $z$ domu rodzinnego, miało bezpośredni związek $z$ jej obecnym życiem „solo”: „myślę, że gdybym wcześniej się usamodzielniła, może też moje życie inaczej by się potoczyło" [K26, L32, B]. Inna kobieta także była głęboko przekonana, że jej życie dzisiaj mogłoby zupełnie inaczej wyglądać, mogłaby mieć partnera lub nawet męża i dzieci, gdyby wcześniej się usamodzielniła, zamiast mieszkać z rodzicami przez trzydzieści dwa lata: „dopiero teraz zaczynam być kobietą, tak to byłam jak taka mała dziewczynka, zawsze przy rodzicach, zawsze bezpieczna" [K30, L35, B]. 
Rodzina jest dla Polaków najważniejszą grupą społeczną, wpływa na poczucie bezpieczeństwa, zadowolenie z życia czy przeciwdziała poczuciu osamotnienia. Wielu singli określało członków swojej najbliższej rodziny jako przyjaciół, powierników sekretów czy doradców w trudnych sytuacjach życiowych. Rodzina dla wielu z nich stała się wspólnotą zbudowaną na uczuciach, których nie można narzucić (Żurek 2001). To poczucie bliskości, więzi, podobieństwo postaw, poglądów i przekonań, wzmacniane wspólnym zamieszkiwaniem, niejednokrotnie stało się tak silne i głębokie, że single nie odczuwają potrzeby budowania własnych związków, ponieważ bliscy zapewniają im - ich zdaniem — zaspokojenie prawie wszystkich najważniejszych emocji i potrzeb (por. Żurek 2005). Bywa też tak, że single, angażując się w sprawy rodzinne i udzielając wsparcia bliskim, „zapominają” o własnych sprawach, na które nie mają już czasu.

\section{NEGATYWNY OBRAZ ZWIĄZKÓW PRZYJACIÓŁ}

Niechęć do stałych związków u singli bazuje także na obserwacjach życia rodzinnego i związków ich przyjaciół oraz znajomych (dwanaście wypowiedzi dotyczyło tego aspektu). Pierwszy motywem, który skłonił część respondentów do życia w pojedynkę, stała się kwestia braku uczciwości w związkach i zdrad, jakich dopuszczają się osoby $z$ zaprzyjaźnionych par. Jeden $z$ respondentów zwrócił uwagę na to, że wielu jego dobrych kolegów nieustannie zdradza swoje żony lub stałe partnerki i niejednokrotnie opowiadają o swoich „podbojach” podczas tak zwanych męskich spotkań. Jego zdaniem, ich zachowanie niewiele różni się od zachowania singli nie mających wobec nikogo żadnych zobowiązań. Respondent przyznał, że $z$ jednej strony będąc singlem rozumie ich sposób bycia, bo najbardziej ceni sobie wolność i niezależność. $Z$ drugiej strony dziwi się jednak, że te związki „jakoś” egzystują, choć nie powinny, jeśli w założeniu są „poważne” [M1, L33, PPL]. Kolejna respondentka stwierdziła, że szczęście wielu znanych jej par jest złudne i pozorne, tworzone „na pokaz”, ponieważ w wielu związkach mężowie zdradzają swoje żony: „znam różne pary i wiem, jak żyją, jakie są to związki i wiem, jak to wygląda na zewnątrz i jak to jest naprawdę. Nie powiem, że nie widzę jak uciekają od siebie, jak siebie zdradzają [...]. I że to nie jest tak różowo i słodko. Sama wiem, jak to jest z tymi zdradami, bo panowie żonaci to mnie bardzo lubią" [K21, L37, PL]. Sama była kiedyś w związku z żonatym mężczyzną, ale przyznała, że nigdy nie chciałaby się znaleźć na miejscu jego żony.

Przyjaciele respondentów niejednokrotnie żyją w nieszczęśliwych związkach, zwłaszcza w małżeństwach lub w konkubinatach, w których urodziły się dzieci. Badani zauważają, że często przez wiele lat rośnie w tych przyjaciołach frustracja, zgorzknienie i niezadowolenie z powodu tego, że w przeszłości dokonali nieodpowiedniego doboru partnera: „znam bardzo dużo osób, które nie znalazły takiej osoby, coś im się wydawało, że znaleźli i rzucili się na coś i to 
kończyło się porażką. Wolę być sam niż być z kimś tylko po to by być" [M16, L30, P]. Kilka osób stwierdziło, że wiele nieudanych związków nadal trwa, ze względu na podjęte zobowiązania, w szczególności wspólne wychowywanie dzieci: „są małżeństwa, których już nic nie łączy, a mieszkają ze sobą jedynie z przyzwyczajenia czy dla dobra dzieci" [K11, L37, B]. Trzy respondentki mówiły o doświadczeniach swoich przyjaciółek, które po rozwodach samotnie wychowują dzieci, co - według badanych — jest ogromnym obciążeniem materialnym i psychicznym. Singielki przyznały, że istnieje ryzyko, iż znajdą się kiedyś w podobnej sytuacji, jeżeli zwiążą się z nieodpowiednim partnerem. Jedna $z$ nich oznajmiła ponadto, że woli żyć w pojedynkę, ponieważ zapewnia to jej swobodę podejmowania decyzji o swoim czasie wolnym: „jak wracam o pierwszej nad ranem do domu i nie muszę się nikomu tłumaczyć, wychodzę kiedy chcę i przychodzę i jest fajnie, a $z$ dzieckiem to już tak nie jest, są kompromisy i wyrzeczenia, ona [przyjaciółka - J.Cz.] nie ma takiego luzu jak ja" [K21, L37, PL].

Innym powodem „sztucznego” - zdaniem badanych - podtrzymywania związku był lęk przed samotnością: „moi znajomi raczej mieszkają ze sobą $\mathrm{w}$ parach, nie wiem, jak to powiedzieć, w konkubinacie chyba, część jest szczęśliwa mam wrażenie, ale reszta jest $\mathrm{w}$ związkach mam wrażenie tylko żeby z kimś być” [K9, L32, P]; „widać w niektórych związkach, że ktoś kurczowo uczepił się drugiej strony. Widać strach w oczach tej osoby, co by było, gdyby tego związku nie było [...] byłby sam, a jest nieprzyzwyczajony do samotności. Widziałem związki tak zwane odgrzewane, gdzie ludzie będący razem w jakimś tam związku rozchodzili się, później do siebie wracali i tak po sześć, siedem razy. To trwało ciągnęło się przez trzy, cztery lata na przykład i były awantury, było obrażanie się, a te osoby tak czy inaczej się ze sobą schodziły. OK mogą to być aspekty fizyczne, właśnie ta chemia na tym poziomie, natomiast nie ta idealna chemia, jeżeli o tym mówimy. W wielu przypadkach wiem, że dokładnie tak było, bo ktoś po prostu się bał być samemu. A druga sprawa to, jeśli ktoś po prostu z przyzwyczajenia tak robił” [M16, L30, P]; „wychodzę z założenia, że nic na siłę, bo wbrew pozorom, niektórzy to robią z moich znajomych, którzy uważają, że bycie samemu jest czymś złym i są $\mathrm{w}$ tych związkach na silę. $Z$ tych obserwacji ich uważam, że nie warto" [K8, L27, PL].

Respondenci poruszali także kwestię odmienności priorytetów i celów życiowych poszczególnych osób w znajomych parach, co - ich zdaniem - niejednokrotnie prowadzi do rozpadu związków: „mam 32 lata i wśród moich znajomych zaczyna się już okres, wśród niektórych par, kiedy ludzie się rozstają, zaczynają się już niektóre pary kruszyć. Na przykład ze względów ekonomicznych, robienia kariery zawodowej jednej osoby, gdzie druga stoi w miejscu" [M28, L35, P]. Kolejnym powodem rozstań jest - zdaniem niektórych singli - także kwestia nudy w związku, brak zmian, ewolucji związku, bierność partnerów, która prowadzi do „zmęczenia” związkiem, rodząc frustracje i motywując do znalezienia kogoś nowego. Jedna $z$ badanych wyznała, że nie chce 
być w podobnym związku jak jej znajomi, ponieważ jest „przerażona” sposobem, w jaki traktują oni siebie nawzajem — bez szacunku, z pogardą, obrażając wulgaryzmami i wyzwiskami: „strasznie się traktują, nie mają do siebie kompletnie zaufania, nie potrafią ze sobą rozmawiać. Potrafią na siebie krzyczeć, obrzucać się wyzwiskami" [K7, L30, PPL].

Część osób stwierdziła, że znajomi czy przyjaciele, którzy egzystują w nieszczęśliwych związkach lub są po rozwodach i rozstaniach, niejednokrotnie odradzają im życie $\mathrm{w}$ parach jako coś, co z założenia jest skazane na porażkę: „jest grupa osób, która wręcz mi to odradza [założenie rodziny - J.Cz.], mimo tego, że sama założyła rodzinę, i gdzieś to na pewno wynika $z$ nieudanego ich życia rodzinnego” [K23, L30, B]; „mam dużo znajomych też takich, którzy się rozwiedli i niestety $\mathrm{w}$ związku $\mathrm{z}$ tym plują sobie trochę $\mathrm{w}$ brodę, że $\mathrm{w}$ ogóle kiedykolwiek podejmowali taką decyzję jak wiązanie się z kimś na stałe. Także oni to w ogóle już przyklaskują temu, że jestem sama" [K15, L38, B].

Kręgi przyjacielskie — obok rodziny — odgrywają bardzo istotną rolę w życiu singli nie tylko ze względu na wspólne spędzanie wolnego czasu czy zapewnianie poczucia bezpieczeństwa, sympatii i akceptacji. Stanowią ponadto miejsce wymiany poglądów i sprzyjają tworzeniu określonych postaw. Obserwacje negatywnych relacji w związkach przyjaciół, przysłuchiwanie się kłótniom, przyglądanie wzajemnemu upokarzaniu się, rozbieżnemu patrzeniu na świat powoduje, że część singli zaczęła postrzegać życie $\mathrm{w}$ parze $\mathrm{w}$ bardzo negatywnym świetle. Dlatego niektórzy w swoich wypowiedziach przyznają otwarcie, że wolą „nie powtarzać historii” swoich przyjaciół czy znajomych i wybierają życie $\mathrm{w}$ pojedynkę.

\section{BRAK DOŚWIADCZEŃ W ZWIĄZKACH WŁASNYCH}

Respondenci, którzy nigdy nie byli w tak zwanym poważnym związku, przyczyny swojego życia w pojedynkę upatrywali także w braku własnego doświadczenia w budowaniu stałych relacji z partnerem. $\mathrm{Na}$ ten temat wypowiedziało się dziesięć osób, które albo nie miały żadnych doświadczeń w życiu we dwoje, albo miały wyłącznie doświadczenia w związkach przelotnych: „nigdy nie byłam w związku, który traktowałam poważnie, nigdy, może ja jestem skazana na samotność po prostu, są tacy ludzie” [K26, L32, B]; „nie mogę się popisać jakimś długodystansowym związkiem, bo nie byłam. Generalnie jak ktoś na mnie patrzy, to ja ciągle jestem sama, nawet nie można zauważyć, że z kimś się spotykam, bo to się już kończy" [K21, L37, PL].

Niektórzy mówili, że powodem braku stałego związku było nieodwzajemnienie uczuć ze strony osoby, w której byli zakochani: „nie byłem zaangażowany na stałe, to znaczy dosyć długo darzyłem bezinteresownie osobę uczuciem, ale to było nieodwzajemnione i dlatego to nie przyniosło żadnego doświadczenia na poziomie związku. Inne kobiety to były związki [przelotne - J.Cz.] wynikające ze wszystkiego tylko nie z miłości [...]. Takiej prawdziwej miłości nigdy nie 
poznałem, tylko miłość rodzinną” [M3, L33, B]; „było kilka takich związków w moim życiu, jednak nigdy nie wynikało z nich nic więcej poza przyjaźnią" [K11, L37, B].

Trzy kobiety stwierdziły, że są same, ponieważ nie potrafią przełamać pewnych barier w swoim zachowaniu w stosunku do mężczyzn: „zaczęłam sobie zdawać sprawę, że ja tych kolesi po prostu odpycham jakąś swoją postawą. Wielu mówiło, że było naprawdę zakochanych, ale po tym albo ja się dziwnie zachowywałam, bo wiedziałam, że nic z tego nie wyjdzie, albo nie wiem... nie chciałam się zaangażować, ryzykować, zawsze mi coś w nich nie odpowiadało [...] czasem mam wrażenie, że postępowałam bardzo egoistycznie i tylko tak ich sobie wykorzystywałam dla rozrywki, żeby nie było mi w życiu nudno i naprawdę nigdy z żadnym nie chciałam być [...], poza tym ja naprawdę czuję się singlem, zawsze tak się czułam [K13, L30, PL]; „to zawsze były związki krótkie, kilka miesięcy, bo ja chyba to za poważnie od razu traktuję te znajomości. Zwykle mam jakiś okresy dwu-, trzymiesięczne w relacjach, a potem mam jakąś dłuższą przerwę, bo ja wtedy się zamykam, szczególnie jak się okazuje, że mi zależało" [K21, L37, PL]; ,jestem nieśmiała i sama bym nigdy nikogo nie zaczepiła. Ktoś by mógł mi spaść na głowę i bym go nie zauważyła, bo jestem taka pierdoła, że się w głowie nie mieści. Ja chodzę w tyle miejsc, nawet głupim pociągiem jeżdżę do Warszawy i normalna kobieta to by z pięćdziesięciu facetów poznała. Są takie kobiety, które tak potrafią, a ja nie. Zwykle mężczyźni mówią, że sprawiam wrażenie niedostępnej albo zajętej, bo mam takie sygnały od mężczyzn. Może robię jakieś dziwne miny, coś w tym musi być. Musi być jakiś powód, że przyjmuję taką pozę. Ciągłe się nad tym zastanawiam. Nie wiem, jak to zmienić" [K26, L32, B].

Część respondentów mówiła, że do samotnego życia zdążyli się przyzwyczaić i traktują je jako naturalny stan rzeczy, który towarzyszy im od zawsze i którego nie chcą zakłócać nieudanymi próbami zbudowania związku: „dla mnie bycie samemu jest jak najbardziej naturalne. Albo miałam takie jednostronne, nieszczęśliwe zakochiwanie się, co jest bardzo przykre. Miałam jeden romans, który przysporzył mi więcej kłopotów niż ostatecznie pożytku, bo bardzo długo z tego wychodziłam, jakieś pół roku i dużo czasu zajął mi taki powrót do tych swoich zwyczajowych czynności i czerpania z nich na powrót przyjemności. [...] I nieprędko byłabym w stanie znowu zaryzykować tego wszystkiego, tego komfortu, jaki mam, dla takiego nieudanego znowu strzału" [K20, L32, B]; „teraz też to są bardzo krótkie relacje, bo uważam, że pewne rzeczy po prostu nie mają sensu, ja znam siebie i wiem, że jak ktoś mi nie odpowiada na początku to bez sensu się zmuszać, bo i tak się wie, że prędzej czy później jakoś tam źle się to skończy, może to błąd nie wiem” [K29, L33, B]; „nigdy nie byłam w związku. Jestem nieufna bardzo i z natury bardzo nieśmiała" [K30, L35, B]; „nie byłam w stałym związku i na razie sobie nie wyobrażam, że moje fantastyczne mieszkanie miałby zburzyć, ten ład, który w jakiś sposób tutaj buduję" [K1, L30, PL]. 
Kobiety, które nie były w stałych związkach, mówiły, że pozostają same, ponieważ - ich zdaniem - nie ma odpowiednich dla nich kandydatów. Niejednokrotnie mają wysoką pozycję społeczną i mówią otwarcie, że w ich otoczeniu brakuje mężczyzn, którzy mogliby im dorównać wykształceniem, zaradnością, przedsiębiorczością itp. Ponadto obarczają winą mężczyzn, że ci zaczęli „bać się” niezależnych i silnych kobiet: „w ogóle coś jest teraz chyba nie tak z facetami, kryzys męskości? Nie wiem, ale wybierają na żony szare myszy, a boją się silnych kobiet. [...] Trudno mi znaleźć silnego faceta, bo jestem bardzo silną kobietą i w dodatku wykształconą, atrakcyjną, więc mnie się faceci po prostu czasem boją. A jak się nie boją, to ci najodważniejsi zawsze są jacyś tacy, no... nieatrakcyjni, albo słabi, albo coś z nimi nie tak. Prawdziwych facetów w ogóle jest mało, a już w moim wieku wszyscy zajęci" [K13, L30, PL]. Inna kobieta zauważa, że jest sama, ponieważ współcześni mężczyźni są niedojrzali emocjonalnie: „dzisiaj faceci często mają albo syndrom Piotrusia Pana, nie mają ochoty się wiązać, albo $z$ dziewczętami w okolicach dwudziestu lat, albo po porostu mają nie tak w głowie" [K20, L32, B]. Ta sama respondentka stwierdziła, że jest jeszcze inny powód tego, że brakuje odpowiednich dla niej mężczyzn: „są tacy mężczyźni koło czterdziestki, którzy by mi odpowiadali, ale oni są już najczęściej uwikłani w jakieś związki. Jeszcze jest opcja, że może spadnie mi ktoś z odzysku. I mam wrażenie, że ci panowie, którzy się rozwodzą, to wiążą się ponownie w przeciągu bardzo krótkiego czasu. Tak mi się wydaje. Nie mogę się oprzeć takiemu wrażeniu, że kobiety stają się harpiami i taki wolny facet, który jest warty uwagi na rynku, jest od razu zajmowany" [K20, L32, B].

Brak doświadczenia w budowaniu długotrwałych związków cechował czternaście kobiet i ośmiu mężczyzn. Jednak to przede wszystkim kobiety przyczyn swojej samotności upatrywały we własnych postawach, obawach, niekiedy lękach związanych z wejściem w „prawdziwy” związek. Niektóre przyczyn takiego stanu rzeczy upatrywały w cechach swojego charakteru. Inne nie analizowały tego szczegółowo, mówiły, że zawsze były same i zdążyły się do tego po prostu przyzwyczaić. Im były starsze, tym wyższe wymagania stawiały wobec swojego potencjalnego partnera i upatrywały przyczyn swojej samotności w braku możliwości znalezienia w rzeczywistości tego „odpowiedniego”. W kobietach dość często ich samodzielność rodziła przekonanie, że same potrafią dobrze funkcjonować $\mathrm{w}$ życiu codziennym, podejmować decyzje, a bycie w związku może oznaczać pewnego rodzaju „zamach” na ich niezależność i samostanowienie.

\section{SZCZĘŚLIWE MAŁŻEŃSTWO RODZICÓW JAKO NIEDOŚCIGNIONY IDEAŁ}

Dwadzieścia pięć osób (z czterdziestu trzech pochodzących z rodzin pełnych) małżeństwa swoich rodziców opisało jako szczęśliwe, zgodne lub dobre: „rodzice są małżeństwem od dwudziestu siedmiu lat i ich związek jest szczęśliwy” [K3]; „rodzice są małżeństwem, dobrym, raczej szczęśliwym” [M19]; 
„moi rodzice są małżeństwem od trzydziestu lat i wydaje mi się, że jest to szczęśliwy związek” [K6]; „moi rodzice są małżeństwem od pięćdziesięciu lat, są szczęśliwym, dobrym małżeństwem” [K10]; „małżeństwo moich rodziców ma trzydziestoczteroletni staż i wydaje mi się, że są szczęśliwym małżeństwem" [K9]. Wśród nich było dziewięciu respondentów, którzy uważając małżeństwo rodziców za nadzwyczaj szczęśliwe, traktowali je jako niedościgniony wzór czy ideał. Często osoby te przyznawały, że trudno im znaleźć odpowiedniego partnera, z którym mogłyby zbudować związek równie szczęśliwy jak małżeństwo rodziców: „moi rodzice są zgodnym, bardzo szczęśliwym małżeństwem, nadają na podobnych falach, jakiś takich poważnych nieporozumień nie ma między nimi. Odkąd się wyprowadziłam to żyją tak dla siebie bardziej, wiadomo, są sami, więc jak dzwonię to albo są na mieście, albo się szykują na imprezę, a to do kina, a to na zakupy razem do galerii, po prostu przeżywają drugą młodość. Fajnie byłoby w ich wieku też tak żyć” [K1, L30, PL]; „,rodzice są ze sobą ponad dwadzieścia pięć lat, potrafią ze sobą gadać do czwartej rano, popijając drinki, sprawiają wrażenie, że ciągle są zakochani” [M2, L28, P]; „moi rodzice są zgodnym małżeństwem, nigdy nie mieli jakiegoś poważnego kryzysu, fajnie byłoby też tak jak oni" [M29, L33, B].

W przypadku tych respondentów być może postrzeganie istoty związku jako takiego przez pryzmat bliskiego doskonałości — zdaniem respondentów - związku rodziców wpływa na to, że trudno im znaleźć partnera, z którym mogliby zbudować związek równie szczęśliwy. Dla nich życie w pojedynkę staje się okresem poszukiwania tego właściwego, idealnego partnera.

\section{ŻYCIE W POJEDYNKĘ JAKO „NATURALNA” KONSEKWENCJA BYCIA JEDYNAKIEM}

Wśród sześćdziesięciu osób biorących udział w badaniu było siedemnaścioro jedynaków. Istotne okazały się wypowiedzi mężczyzn-jedynaków, którzy twierdzili, że ich singlowanie jest niejako konsekwencją „przyzwyczajenia się” do samotnego trybu życia, pewnego rodzaju egocentryzmu, a nawet egoizmu. Takie stanowisko zajęło siedmiu spośród dziesięciu mężczyzn, którzy byli jedynakami. Do tej kategorii należało także siedem kobiet, jednak żadna z nich nie wysunęła podobnych przypuszczeń.

Niektóre wypowiedzi mężczyzn-jedynaków wskazywały, iż uważali oni, że brak doświadczeń $\mathrm{w}$ relacjach $\mathrm{z}$ rodzeństwem spowodował $\mathrm{u}$ nich niedostateczne rozwinięcie umiejętności kształtowania relacji z innymi ludźmi w ogóle. Jeden stwierdził: „mam o sobie bardzo wysokie mniemanie i czasami mogę się zamieniać $\mathrm{w}$ narcyza i się nosić $\mathrm{z}$ moimi myślami na własny temat [...], nie wiem, może i miało wpływ to, że jestem jedynakiem, nigdy nie musiałem się niczym z nikim dzielić, wypracowywać kompromisów, byłem sobie panem własnego losu i nadal jestem" [M11, L30, PL]. Inny natomiast zdecydowanie podkreślił, że jedną z przyczyn jego singlowania stanowi właśnie to, że jest 
jedynakiem: „wydaje mi się, że to jest naturalna kontynuacja tego, co się wiąże $z$ byciem jedynakiem, rodzice zapatrzeni $w$ ciebie. To nie jest dobre, bo wypacza i tworzy duże bariery w kontaktach międzyludzkich po prostu, społecznych. $\mathrm{Ci}$, co mają rodzeństwo, wiedzą, że muszą się dzielić, ich zdanie nie będzie zawsze na wierzchu. Nie wszyscy jedynacy są tacy, ale są takie niepoprawne egzemplarze jak ja" [M20, L33, PPL]. Kolejny respondent przyznał otwarcie, że gdyby miał rodzeństwo - co było jego wielkim pragnieniem — łatwiej byłoby mu nawiązywać kontakty z innymi ludźmi, mogłoby to przyczynić się do jego większej otwartości na możliwość nawiązania znajomości z kobietami [M23, L33, B]. Jeszcze inny mężczyzna od trzech lat mieszka w pojedynkę i przyznaje, że ponieważ jest jedynakiem, do życia w pojedynkę po prostu się przyzwyczaił: „jestem jedynakiem i zawsze miałem ten swój pokoik, mi to nie przeszkadzało, bo się tam zamykałem jak chciałem, zawsze sam. Ewentualnie czasem zadzwoniłem czy wyszedłem. Zawsze było się samemu i nie miałem $z$ tym problemu, co mają niektórzy, którzy nie wyobrażają sobie tak mieszkać jak ja teraz, ja się po prostu przyzwyczaiłem" [M13, L30, P]. Inny rozmówca choć nie do końca był pewien, czy jego życie w pojedynkę może być warunkowane tym, że nie ma rodzeństwa, przyznał jednak: „zawsze było mi łatwiej samemu, bo byłem jedynakiem, więc dla mnie miało to wiele plusów, ale nie sądzę, że teraz tak jest dlatego, że wychowywałem się sam, chociaż może" [M28, L35, P].

To, że żadna $z$ kobiet-jedynaczek nie poruszyła tej kwestii, można wytłumaczyć różnicami w procesie socjalizacji kobiet i mężczyzn, które sprawiają, że kobiety określają siebie poprzez wartości i relacje interpersonalne oraz kontekst społeczny - celami pierwszoplanowymi są dla nich opiekowanie się i przejawianie troski o drugiego człowieka. Mężczyźni myślą o świecie w przez pryzmat siebie - celami pierwszoplanowymi dla nich są zachowanie własnej niezależności i indywidualności (Czyżowska 1993).

\section{INNE PRZYCZYNY ŻYCIA W POJEDYNKE}

W wypowiedziach trzech respondentek pojawiła się także kwestia przekazywania określonych treści socjalizacyjnych. Choć wypowiedzi takich było niewiele, warto o nich wspomnieć. Ich autorki były zdania, że na dotychczasowy wybór przez nie życia w pojedynkę miał wpływ sposób wychowania i wpojone im wartości. Istotne znaczenie, według tych singielek, miał fakt, że głównie matki kładły nacisk na nauczenie córek samodzielności życiowej i autonomii $\mathrm{w}$ podejmowaniu decyzji. Jedna $z$ nich stwierdziła, iż „świetnie sobie radzi sama", potrafi podejmować trudne decyzje oraz organizować sobie życie i choć chciałaby mieć w przyszłości stałego partnera, przyznaje, że go właściwie nie potrzebuje: „zawsze byłam samodzielna i tym chyba odstraszam mężczyzn, tą samodzielnością. Nigdy nie prosiłam o pomoc, bo ja nie jestem taką małą, biedną kobietką, która nie może gwoździa sama przybić. Ostatnio doszłam do tego, że tak muszę robić, bo oni chcą być potrzebni i taka Zosia Samosia, 
to jest błąd" [K26, L32, B]. Podobnie inna respondentka, która także przede wszystkim była uczona przez matkę samodzielności, zaradności życiowej oraz niezależności, przyznała, iż tak naprawdę nigdy nie wykształciła w sobie potrzeby dzielenia $z$ kimś na stałe życia, mimo że uprzednio była w kilkuletnim związku [K22, L38, PPL]. Trzecia z kolei stwierdziła, że na jej stosunek do mężczyzn niewątpliwie miał wpływ sposób, w jaki matka traktowała swojego męża, czyli jej ojca: „rodzice raczej są szczęśliwi, mama jest bardzo silną kobietą, bardzo. Tata u mnie sprząta, gotuje, robi zakupy, po prostu zajmuje się domem, który mama przez większą część życia utrzymuje finansowo i podejmuje najważniejsze decyzje. Trochę myślę, że taki przykład z niej brałyśmy z siostrą i teraz, niestety, to się przekłada na nasze relacje $z$ mężczyznami. Moja siostra też jest taka jak ja, też narzuca swoje zdanie obecnemu chłopakowi. Tak trochę bezkompromisowo podchodzimy, jak księżniczki, my możemy pokazać pazurki i egzekwować, co chcemy, a facet nie może się nawet odezwać, a raczej mało który to znosi" [K13, L30, PL]. Matka wielokrotnie przestrzegała respondentkę, żeby dobrze się zastanowiła, z kim się zwiąże w przyszłości, „żeby się później nie męczyć z niewłaściwym mężczyzną". Kobiecie tej nigdy nie udało się stworzyć „zdrowego, normalnego związku z mężczyzną”, ponieważ z jednej strony żywiła głęboko zakorzenione przekonanie, że dominująca postawa matki jest właściwa i uzasadniona, z drugiej strony jednak była świadoma, że relacje partnerskie wymagają zupełnie innego podejścia.

Kolejne osoby opowiadając o przyczynach swojego życia w pojedynkę, powołały się na zbyt silne zaangażowanie $\mathrm{w}$ życie pozostałych członków rodziny i pomoc im, na to, że ze względu na więzi rodzinne nie potrafią odmawiać pomocy bliskim. Warto zauważyć, że w ich wypowiedziach wyczuwało się nutę żalu, iż poświęcają za dużo czasu na sprawy rodzinne, zaniedbując własne życie: „W ogóle często mam rodzicom załatwiać jakieś sprawy na mieście, więc do mnie dzwonią i traktują mój czas jakby należał do nich. Mam trochę tego dosyć, bo nie pytają, czy mogę im coś załatwić, tylko że to i to jest do załatwienia" [K1, L30, PL]. Kolejny przykład ze swojego życia przytoczyła kobieta mieszkająca z rodzicami i babcią, którą się opiekowała. Często pomagała także siostrze w opiece nad dzieckiem. Stwierdziła: „myślę, że jestem osobą mało konfliktową, bardzo dużo pomagam siostrze, rodzicom i opiekuję się babcią, czasem już nie mam za dużo czasu dla siebie" [K2, L29, P]. Silnego wsparcia emocjonalnego członkom swojej rodziny udzielała inna respondentka, która przyznała, że dopiero koleżanka uświadomiła jej, jak wiele czasu poświęca rodzinie i jej problemom, zamiast zająć się własnym życiem: „ja zawsze się o wszystkich martwiłam i do pewnego czasu byłam pochłonięta bardziej życiem rodziny, moich sióstr, i nie bardzo miałam czas dla samej siebie" [K30, L35, B].

Innym czynnikiem, na który powołał się jeden z respondentów, był brak więzi z rodzicami w dzieciństwie. Opisując siebie jako człowieka bardzo rodzinnego i ciepłego, wielokrotnie podkreślał, że jego silna potrzeba bycia $\mathrm{w}$ „prawdziwym, głębokim i długotrwałym związku" [M3, L33, B] może wynikać z nie- 
zaspokojonej w dzieciństwie potrzeby bliskości z rodzicami. Ogromne pragnienie posiadania partnerki, jego zdaniem, jest tłumione i blokowane przez strach wywołany wspomnieniami bardzo negatywnych relacji, jakie panowały między rodzicami zarówno przed rozwodem, jak i później, wyraźnie zachował je w pamięci: „moi rodzice są po rozwodzie, już długi czas było między nimi niedobrze. Jak się rozeszli, byłem nastolatkiem, chciałem im zrobić na złość, uciekałem $z$ domu i straciliśmy kontakt. Oboje teraz żyją osobno, w pojedynkę. Ojciec jest alkoholikiem, mieszka ze swoją matką, a matka mogłaby sobie kogoś znaleźć, ale nie chce, chyba ma bardzo duży uraz po związku z moim ojcem, nie chce mieć nic z nim do czynienia, woli być sama" [M3, L33, B].

Interesującej wypowiedzi udzielił także mężczyzna, który bez wahania określił małżeństwo swoich rodziców jako niezwykle udane i szczęśliwe, jednak $\mathrm{w}$ jego wypowiedziach pojawiły się twierdzenia świadczące o negatywnym wpływie relacji między rodzicami na niego samego. Obwiniał bowiem rodziców, że ich wzajemna bliskość odsunęła go na dalszy plan jako dziecko: „oni zawsze byli dla siebie najważniejsi, czasem mam wrażenie, że ja schodziłem na drugi plan, bo ich relacja była dla nich ważniejsza" [M2, L28, P]. Przyczyny swoich niepowodzeń $w$ nawiązaniu bliskich stosunków $z$ dziewczynami upatruje $\mathrm{w}$ kłopotach $\mathrm{z}$ samoakceptacją i niskim poczuciu własnej wartości, do czego — jego zdaniem - przyczynili się swoim zachowaniem rodzice.

\section{KONKLUZJE}

Wbrew powszechnej opinii - najczęściej lansowanej przez środki komunikacji masowej - przyczyn życia w pojedynkę polskich singli nie należy szukać wyłącznie w zaangażowaniu w pracę zawodową, tłumaczyć brakiem czasu na budowanie trwałych związków, upatrywać ich w miejskim stylu życia lub obecnej modzie na życie „solo”. W istocie przyczyn, dla których ludzie stają się singlami, jest bardzo wiele. Można wyróżnić kilka typów singli.

Pierwszych nazwałam singlami „zranionymi”. Tacy ludzie posługują się w życiu mottem „wolę być sam/wolę być sama, niż znowu cierpieć”. Do tej kategorii zaliczyłam osoby, które jako główny motyw samotnego życia podają przede wszystkim negatywne doświadczenia dotyczące życia we dwoje. Część $z$ nich przeżyła zawody miłosne, zostali porzuceni lub zdradzeni przez partnerów, z którymi tworzyli trwałe i, ich zdaniem, poważne związki. Nie myślą o kolejnych relacjach, bo nie potrafią zaufać drugiej osobie, przekonani, że sytuacja może się powtórzyć. Są to także osoby, które mimo usilnych prób nie zdołały zbudować trwałego związku, angażowały się jedynie w nieszczęśliwe, przelotne relacje. Są to też single, którzy przeżyli nieszczęśliwą, nieodwzajemnioną miłość i nie mieli szansy zbudowania związku z osobą, w której byli zakochani. Single „zranieni” często odczuwają żal i rozgoryczenie z powodu źle ulokowanych uczuć. Wybierają życie $\mathrm{w}$ pojedynkę, by chronić się przed kolejnymi niepowodzeniami. 
Drugi typ to single „be zko m p ro mi s ow i”, wyznający ideę „lepiej być samemu niż byle jak i z byle kim". Tę sentencję często słyszałam w rozmowach z osobami, które opowiadając o tym, dlaczego żyją same, mówiły, że „napatrzyły" się na negatywne relacje w związkach najbliższych sobie osób i nie chcą tych negatywnych modeli powielać. Single ci najczęściej pochodzili z rozbitych lub nieszczęśliwych rodzin, w których rodzice, choć pozostawali formalnie małżeństwem, byli obcymi dla siebie ludźmi. Respondenci mówili także o nieszczęśliwych związkach rodzeństwa i przyjaciół. Bliscy niekiedy sami zachęcali ich do życia w pojedynkę, żeby nie cierpieli tak jak oni. Do tej kategorii zaliczyłam także osoby długo pozostające w nieudanych związkach, które w końcu rozpadły się z powodów niezgodnych charakterów i odmiennych priorytetów życiowych partnerów.

Trzeci typ to single „marzyciele”, którym bliska jest idea: „jestem sam/jestem sama, bo czekam na swój ideał". Osoby takie były głęboko przekonane, że spotkają na swojej drodze „drugą połówkę” czy „bratnią duszę”, z którą ułożą sobie życie. Byli wśród nich „odwieczni” single, którzy nigdy nie byli w poważnym związku, oraz tacy, którzy zerwali dotychczasowe relacje, ponieważ partnerzy nie spełniali ich oczekiwań. Dla innych niedoścignionym wzorem związku stało się małżeństwo rodziców. Wszystkie te osoby łączy głębokie przekonanie, że warto czekać na „księcia lub księżniczkę z bajki” i dlatego życie w pojedynkę jest dla nich czasem oczekiwania na wymarzonego partnera lub partnerkę.

Czwarty typ singli „miotających się” reprezentują osoby, które mówią: „jestem singlem, bo tak wyszło”. To osoby, których związki rozpadły się w wyniku okoliczności zewnętrznych, takich jak odległość geograficzna czy zaangażowanie $\mathrm{w}$ pracę zawodową. Brak możliwości częstego kontaktu osobistego z partnerem, wspólnego spędzania czasu prowadził do ograniczania spotkań i „wygaśnięcia uczuć”. Do kategorii tej należą także ci, którzy mówili o swoim silnym zaangażowaniu w sprawy rodzinne i braku czasu dla siebie, który mogliby poświęcić na randki. Często deklarowali, że choć nie mają czasu lub sposobności, by szukać partnera, to chcieliby się z kimś związać.

Do piątej kategorii zaliczyłam singli „s z c z ęśli w y ch”, którzy traktują „życie solo" jako swoistego rodzaju przerwę lub odpoczynek po poważnych związkach. Niejednokrotnie opowiadali, że ich związki były „za długie”, nieudane, a relacje „podtrzymywane na siłe”. Towarzyszyło tym związkom wiele konfliktów i złych emocji. Dlatego życie w pojedynkę jest dla nich obietnicą samorealizacji lub powrotem do dawnych pasji, których nie mogli realizować będąc W związku.

Ostatnią kategorię stanowią single „oswojeni”, którzy mówią o sobie „przyzwyczaiłem się/przyzwyczaiłam się do bycia singlem”. Do tej grupy zaliczyłam osoby od zawsze żyjące w pojedynkę i traktujące ten stan rzeczy jako naturalny, nie chcą burzyć ładu w swoim uporządkowanym świecie, ani rezygnować z rytuałów i codziennych przyjemności na rzecz partnera. W tej kategorii 
znalazły się osoby, które są silnie związane z rodzicami, długo z nimi mieszkały lub mieszkają nadal. Wszystkie ich deficyty emocjonalne i potrzebę poczucia akceptacji zaspokajają ich najbliżsi, dlatego często mówią, że „nikogo więcej już nie potrzebują". Do tej grupy zaliczyłam również kobiety, które uważają, że ponieważ długo są same, w stosunku do mężczyzn zachowują się w sposób „nienaturalny” i nie potrafią już tego zmienić, mówiąc, że życie „solo” jest dla nich „normalne”, a bycie w związku to stan „,anormalny”. Znaleźli się tu także mężczyźni, którzy uważają swoje życie „solo” za naturalną konsekwencję bycia jedynakiem.

Analizując swoje doświadczenia i obserwacje, badani z dużą dozą autorefleksji niejednokrotnie zastanawiają się, jak głębokie i prawdziwe musi być uczucie do drugiej osoby, aby można było z nią zbudować długotrwały i poważny związek. Nie chcą powtarzać swoich lub cudzych błędów, chcą budować związki dobrej jakości, nie tylko o cechach miłości romantycznej, wyidealizowanej, ale przede wszystkim oparte na silnej więzi, wynikającej ze wspólnoty wartości i priorytetów życiowych. Należy pamiętać, że przyczyny życia w pojedynkę - tutaj przedstawione jedynie skrótowo - są złożone. Dla jednych jest to konsekwencja pozytywnych wyborów życiowych, dla innych „mniejsze zło”.

\section{BIBLIOGRAFIA}

Adams Margaret, 1976, Single Blessedness: Observations on the Single Status in Married Society, Basic Books, New York.

Austrom Douglas R., 1984, The Consequences of Being Single, Peter Lang Publishing, New York.

Beck-Gernsheim Elisabeth, 1998. On the Way to a Post-familial Family: From a Community of Need to Elective Affinities, „Theory, Culture and Society”, t. 15, nr 3-4.

Cargan Leonard, Melko Matthew, 1982, Singles: Myths and Realities, Sage, Beverly Hills.

Chandler Joan, 1991, Women without Husbands: An Exploration of the Margins of Marriage, St. Martin's Press, New York.

Chudacoff Howard P., 1999, Age of the Bachelor: Creating an American Subculture, Princeton University Press, Princeton NJ.

Cudak Henryk, 2001, Problemy uspotecznienia dzieci jedynych $w$ rodzinie wspótczesnej, w: Zbigniew Tyszka (red.), Wspótczesne rodziny polskie - ich stan $i$ kierunek przemian, Wydawnictwo Naukowe UAM, Poznań.

Czernecka Julita, 2008, Polski singiel: stereotyp $w$ mediach a autowizerunek, w: Ewa Malinowska (red.), Stereotypy a rzeczywistość, Tercja, Łódź.

Czyżowska Dorota, 1993, Sprawiedliwościowa koncepcja moralności a różnice $w$ rozumowaniu moralnym kobiet i mężczyzn, „Kwartalnik Polskiej Psychologii Rozwojowej”, nr 1-4.

Dąbrowska Zofia, 2001, Matżeństwa w Polsce wspótczesnej, „Roczniki Socjologii Rodziny”, t. 13.

Dalton Sandra T. 1992, Lived Experience of Never-married Women, „Mental Health Nursing”, t. 13, nr 2 .

De Paulo Bella M., Morris Wendy L., 2005, Singles in Society and in Science, „Psychological Inquiry", t. 16, s. 57-83. 
Edwards Marie, 1977, Coupling and Re-coupling vs. the Challenge of Being Single, „Personnel and Guidance Journal", May.

Edwards Marie, Hoover Eleanor, 1974, The Challenge of Being Single, Signet, New York.

Francese Peter, 2003, Well enough Alone, „American Demographics”, November, s. 32-33 .

Gałkowska Agnieszka, 1995, Małżenstwo rodziców a obraz siebie, „Problemy Rodziny”, nr 2.

Giddens Anthony, 2006, Przemiany intymności. Seksualność, miłość i erotyzm we wspótczesnych społeczeństwach, tłum. Alina Szulżcka, Wydawnictwo Naukowe PWN, Warszawa.

Gordon Tuula, 1994, Single Women: On the Margins?, New York University Press, Washington Square, NY.

Gove Walter R., Shin Hee-Choon, 1989, The Psychological Well-Being of Divorced and Widowed Men and Women, „Journal of Family Issues”, t. 10, s. 122-144.

Grzeszczyk Ewa, 2005, Pojedyncze, profesjonalistki... „single professional women” $w$ Polsce i na świecie, „Kultura i Społeczeństwo”, nr 2.

Hoorn Willem D., 2000, Alleen wonen: liever wel of liever niet, „Demos”, marzec.

Jałowiecki Bohdan, Szczepański Marek, 2002, Miasto i przestrzeń w perspektywie socjologicznej, Scholar, Warszawa.

Kaiser Cheryl R., Kashy Deborah A., 2005, The Contextual Nature and Function of Singlism, „Psychological Inquiry”, t. 16, s. 122-126.

Kaslow Florence W., 1992, Thirty-plus and Not Married, w: Barbara Rubin Wainrub (red.), Gender Issues Across the Life Cycle, Springer, New York.

Kuhn Manford, 1955, How Mates Are Sorted, w: Howard Becker, Reuben Hill (red.), Family, Marriage and Parenthood, Heath, Boston.

Paprzycka Emilia, 2007, „Jaka jest nowa samotna kobieta?”, Ogólnopolski Zjazd Socjologiczny, Zielona Góra (materiały konferencyjne).

Pospiszyl Kazimierz, 1996, Czy zmierzch rodziny patriarchalnej?, „Problemy Rodziny”, nr 6.

Przybył Iwona, 2001, Źródła wiedzy o rolach małżeńskich, „Roczniki Socjologii Rodziny”, t. 13.

Slany Krystyna, 2002, Życie w samotności, „ResPublica Nowa”, nr 12.

Sokal Urszula, 2001, Czynniki wptywające na kształtowanie się więzi w rodzinie, „Roczniki Socjologii Rodziny", t. 13.

Stein Peter J. ,1975, Singlehood: An Alternative to Marriage, „The Family Coordinator”, October.

Stein Peter J., 1976, Single, Englewood Cliffs, Prentice-Hall, NJ.

Stein Peter J., 1981, Single Life: Unmarried Adults in Social Context, St. Martin's Press, New York.

Schwartzberg Natalie, Berliner Kathy, Jacob Demaris,1995, Single in a Married World: A Life Cycle Framework for Working with the Unmarried Adult, Norton, New York.

Tymicki Krzysztof, 2001, Starokawalerstwo $i$ staropanieństwo. Analiza zjawiska, „Studia Socjologiczne", nr 4.

U.S. Cenzus Bureau, 2004, Mini-historical Statistics, Statistical Abstract of US on Line, Tablica HS-11 Matrial status of the population by sex: 1900-2002, http://www.census.gov/statab/hist/HS-11.pdf.

Yamada Masahiro, 1999, Parasaito shakai no yukue, Chikuma Shobō, Tokyo [The Era of Parasite Singles]. 
Żurek Aldona, 2001, Źródła wiedzy o rolach małżeńskich, „Roczniki Socjologii Rodziny”, t. 13.

Żurek Aldona, 2005, Relacje taczace młodych singli z rodzicami, w: Witold Wrzesień, Aldona Żurek, Iwona Przybył (red.), Rodzice i ich dzieci w tańcu pokoleń, Wydawnictwo Naukowe UAM, Poznań.

\section{SINGLE-MAN AND SINGLE-WOMAN ABOUT LIVING ALONE}

Summary

The article presents Polish singles' main arguments for living alone that are from micro-social level, e.g. unfortunate experiences in previous relationships, negative memory of one's parents relationship, very strong family ties, negative impression of friends' relationships, no experience in building lasting relationships, happy marriage of one's parents as an unachievable ideal, living alone as a natural consequence of being an only child etc. These general arguments have been described in relation to various reasons for which the single-men and single-women have decided to live alone. The article is based on empirical surveys which were carried out at the turn of 2006/2007.

\section{Key words/słowa kluczowe}

singles / single; living alone / życie w pojedynkę; alone by choice / samotność z wyboru 